\title{
Kewenangan Penyidik Kepolisian untuk Melakukan Penyidikan terhadap Kasus Pidana Keterangan Palsu di Persidangan Pengadilan
}

\author{
Priscilla Tazia Sulaiman \\ Airlangga University, Indonesia \\ Priscillatazia@gmail.com
}

\begin{abstract}
Article 160, paragraph (4), Act Number 8, Year 1981, Code of Criminal Procedure states that witnesses are obliged to take an oath in accordance with their religion, before providing a statement in courts. It is aimed to prevent witnesses from providing a fake statement, as it is strictly prohibited in Article 174 Code of Criminal Procedure and Article 24, Criminal Code. In practice, it has resulted in contentious views of the application of such articles. In one regard, the procedure settles the problem of fake statements, as it does not require a report or an investigation, but only the ruling of judges. In contrast, another argument states that it does not require the ruling of judges, so that witnesses can be reported to police for investigation. This article revisits the power of police to investigate a fake statement in courts. By using legal research, the results of the study show that Article 242 Criminal Code remains to be applied in cases of fake statements, with the absence of a judge's ruling. Therefore, police remains to be granted the power to investigate fake statements.
\end{abstract}

KEYWORDS: Investigation, Witness, Fake Statement.

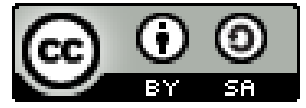

Copyright $\odot 2018$ by Author(s)

This work is licensed under a Creative Commons Attribution-ShareAlike 4.0 International License. All writings published in this journal are personal views of the authors and do not represent the views of this journal and the author's affiliated institutions.

\section{HOW TO CITE:}

Sulaiman, Priscilla Tazia. "Kewenangan Penyidik Kepolisian untuk Melakukan Penyelidikan terhadap

Kasus Pidana Keterangan Palsu di Persidangan Pengadilan" (2018) 5:2 Lentera Hukum 209-226.

Submitted: January 25, 2018 Revised: April 23, 2018 Accepted: June 29, 2018 


\section{PENDAHULUAN}

Pembuktian memegang peranan penting dalam proses pemeriksaan sidang pengadilan. Dengan pembuktian dapat ditentukan nasib seorang terdakwa. Melalui alat-alat bukti di persidangan seorang terdakwa dapat dinyatakan bersalah kemudian dihukum atau sebaliknya dinyatakan tidak bersalah dan kemudian dibebaskan dari segala hukuman. Alat-alat bukti yang sah diatur dalam Pasal 184 ayat (1) Kitab Undang-Undang Hukum Acara Pidana (KUHAP) meliputi keterangan saksi, keterangan ahli, surat, petunjuk dan keterangan terdakwa.

Tulisan ini akan mengkaji lebih dalam tentang alat bukti berupa keterangan saksi. Keterangan saksi merupakan alat bukti yang paling utama dalam perkara pidana. Dapat dikatakan bahwa tidak ada perkara pidana yang luput dari pembuktian keterangan saksi. Hampir semua pembuktian perkara pidana selalu berstandar pada pemeriksaan keterangan saksi. Sekurang-kurangnya, disamping pembuktian dengan alat bukti yang lain, diperlukan pembuktian dengan alat bukti keterangan saksi. ${ }^{1}$

Peranan saksi dalam setiap persidangan perkara pidana sangat penting karena seringkali keterangan saksi dapat mempengaruhi dan menentukan kecenderungan keputusan hakim. Seorang saksi dianggap memiliki kemampuan untuk dapat menentukan kemana arah keputusan hakim. ${ }^{2}$ Pengertian seorang saksi menurut Pasal 1 angka 26 KUHAP, yaitu orang yang dapat memberikan keterangan guna kepentingan penyidikan, penuntutan dan peradilan tentang suatu perkara pidana yang ia dengar sendiri, ia lihat sendiri dan ia alami sendiri. Sedangkan keterangan saksi menurut Pasal 1 angka 27 KUHAP merupakan salah satu alat bukti dalam perkara pidana berupa keterangan dari saksi mengenai suatu peristiwa pidana yang ia dengar sendiri, ia lihat sendiri dan ia alami sendiri dengan menyebut alasan dan pengetahuannya itu.

Sebagai salah satu alat bukti yang sah, sebagaimana diatur dalam Pasal 184 ayat (l) KUHAP, sebelum saksi memberikan keterangan dalam persidangan, saksi wajib mengucapkan sumpah menurut agamanya masing-masing sesuai dengan ketentuan Pasal 160 ayat (3) KUHAP. Isi sumpah tersebut menyatakan bahwa saksi akan memberikan keterangan yang sebenarnya dan tidak lain daripada yang sebenarnya.

Dua hal yang perlu diperhatikan dalam ketentuan tersebut, yaitu "sumpah atau janji menurut cara atau agamanya masing-masing" dan "akan memberikan keterangan yang sebenarnya". Beralaskan sumpah menurut agamanya, diharapkan saksi akan tunduk dan patuh pada hukum agamanya, dengan keyakinan apabila melakukan kebohongan atau dusta dalam memberikan kesaksian akan mendapat laknat Tuhan. ${ }^{3}$

Mengenai keterangan seorang saksi di dalam pemeriksaan pengadilan yang disangka palsu, maka Pasal 174 KUHAP mengatur bahwa hakim ketua sidang akan memperingatkan kepadanya supaya memberikan keterangan yang sebenarnya serta mengemukakan ancaman pidana yang dapat dikenakan kepadanya bila dia tetap memberikan keterangan palsu. Namun

1 M. Yahya Harahap, Pembahasan Permasalahan dan Penerapan KUHAP Pemeriksaan Sidang Pengadilan, Banding, Kasasi, dan Peninjauan Kembali, Edisi Kedua, Sinar Grafika, Jakarta, 2016, hlm. 286.

2 Muhadar, Edi Abdullah, Husni Thamrin, Perlindungan Saksi dan Korban dalam Sistem Peradilan Pidana, Putra Media Nusantara, Surabaya, 2009, hlm. l.

3 Hendar Soetarna, Hukum Pembuktian dalan Acara Pidana, Alumni, Bandung, 2011, hlm. 53. 
apabila saksi tetap pada keterangannya, hakim ketua sidang karena jabatannya atau atas permintaan penuntut umum atau terdakwa dapat memberi perintah agar saksi itu ditahan untuk selanjutnya dituntut perkara dengan dakwaan sumpah palsu.

Setelah itu penitera segera membuat berita acara pemeriksaan sidang yang memuat keterangan saksi tersebut dengan menyebutkan alasan persangkaan yang menyatakan bahwa keterangan saksi itu adalah palsu dan berita acara tersebut ditandatangani oleh hakim ketua sidang serta panitera lalu diserahkan kepada penuntut umum untuk diselesaikan menurut ketentuan undang-undang. Dalam hal ini, bila perlu hakim ketua sidang menangguhkan sidang dalam perkara semula sampai pemeriksaan perkara pidana terhadap saksi yang diduga memberikan keterangan palsu tersebut selesai.

Sumpah berfungsi sangat penting dalam menemukan kebenaran. Di samping penyumpahan penerapannya berlaku mutlak, hukum pidana mengatur pelanggaran tidak dipenuhinya kewajiban bersumpah, Kitab Undang-Undang Hukum Pidana (KUHP) mengatur tentang penghianatan atau kemungkaran terhadap sumpah, yaitu dalam hal saksi yang telah bersumpah sebelum memberikan keterangan, ternyata keterangan yang diberikan merupakan keterangan palsu. ${ }^{4}$

Sanksi atas perbuatan memberikan keterangan palsu demikian diatur dalam Pasal 242 ayat (1) dan ayat (2) KUHP. Dalam praktek peradilan telah berkembang perbedaan pendapat mengenai penerapan ketentuan Pasal 174 ayat (3) KUHAP berkenaan dengan penyidikan perkara keterangan palsu. Dalam suatu persidangan pidana memberikan keterangan palsu di depan persidangan, di mana timbul pendapat bahwa kasus keterangan palsu di persidangan tidak memerlukan penyidikan oleh kepolisian, berita acara yang dibuat oleh panitera dan ditandatangani oleh hakim ketua dan panitera dianggap sudah cukup untuk melanjutkan proses penuntutan dan pemeriksaan di persidangan oleh hakim.

Apabila di dalam persidangan perkara semula tidak ada penetapan dari hakim bahwa saksi tersebut telah memberikan keterangan palsu maka saksi tersebut tidak dapat dilaporkan dan disidik oleh kepolisian karena yang berhak menetapkan seseorang telah memberikan keterangan palsu di depan persidangan hanyalah hakim. Hal ini biasa dikemukakan oleh penasihat hukum dari terdakwa sebagai jawaban atas dakwaan oleh Penuntut Umum. Sebaliknya pihak lain yang berperkara manganggap bahwa perlu dilakukan penyidikan oleh kepolisian karena dianggap panitera atau pengadilan tidak memiliki fungsi dan kewenangan melakukan penyidikan tindak pidana.

Penyidikan merupakan suatu tahap terpenting dalam kerangka hukum acara pidana di Indonesia karena pihak penyidik berupaya mengungkapkan fakta-fakta dan bukti-bukti atas terjadinya suatu tindak pidana serta menemukan tersangka pelaku tindak pidana tersebut. Dalam rangka menyelenggarakan tugas sebagai penegak hukum khususnya dalam proses pidana, kepolisian memiliki kewenangan sebagai penyelidik dan penyidik. KUHAP membedakan antara penyelidik dan penyidik. Esensi penyelidikan adalah untuk mencari dan menemukan suatu

$4 \quad$ Ibid, hlm. 55 
peristiwa pidanaSedangkan penyidikan adalah untuk mencari serta mengumpulkan bukti yang menjelaskan tentang tindak pidana yang terjadi dan menemukan tersangkanya.

Menurut de Pinto, menyidik (opsporing) berarti pemeriksaan permulaan oleh pejabatpejabat yang ditunjuk oleh undang-undang segera setelah terjadi sesuatu pelanggaran hukum. ${ }^{5}$ Pengertian saksi tertuang dalam Pasal 1 angka 26 KUHAP, yaitu:

"saksi adalah orang yang dapat memberikan keterangan guna kepentingan penyidikan, penuntutan dan peradilan tentang suatu perkara pidana yang ia dengar sendiri, ia lihat sendiri dan ia alami sendiri."

Pada umumnya semua orang dapat menjadi saksi, namun KUHAP mengatur pengecualian atau larangan menjadi saksi yaitu karena hubungan keluarga seperti keluarga sedarah, semenda saudara ibu atau saudara bapak, hubungan karena perkawinan, suami atau istri terdakwa meskipun sudah bercerai atau yang bersama-sama terdakwa. ${ }^{6}$

Di samping itu, Pasal 170 KUHAP juga mengatur bahwa hubungan pekerjaan dapat diminta dibebaskan dari kewajiban memberi keterangan sebagai saksi. Misalnya pekerjaan atau jabatan yang menentukan adanya kewajiban menyimpan rahasia ditentukan oleh peraturan perundang-undangan. Misalnya Dokter yang harus merahasiakan penyakit yang diderita oleh pasiennya. Sedangkan yang karena martabatnya dapat mengundurkan diri adalah Pastor agama Katolik Roma. Ini berhubungan dengan kerahasiaan orang-orang yang melakukan pengakuan dosa kepada Pastor tersebut. ${ }^{7}$ Pasal 170 KUHAP menyatakan bahwa terbebasnya seseorang dari kewajiban untuk memberikan keterangan sebagai saksi merupakan permintaan atau pengajuan. Apabila yang bersangkutan bersedia menjadi saksi, saksi tersebut dapat diperiksa oleh hakim. Alternatif lain adalah apabila hakim mengabulkan permintaan pembebasan sebagai saksi, seorang saksi tersebut bisa terbebas sebagai saksi. Dengan demikian, pengecualian menjadi saksi karena harus menyimpan rahasia jabatan atau karena martabatnya merupakan pengecualian relatif. ${ }^{8}$

Pada prinsipnya keterangan yang harus diberikan oleh seorang saksi dalam persidangan adalah memberi keterangan yang sebenarnya atau menurut fakta yang terjadi sesuai dengan janji yang diucapkannya. Saksi dilarang memberikan keterangan bohong. ${ }^{9}$ Dalam menilai dan mengkonstruksi kebenaran keterangan para saksi, Pasal 185 ayat (6) menuntut kewaspadaan hakim untuk sungguh-sungguh memperhatikan kesesuaian keterangan saksi. Artinya, keterangan saksi harus bersesuaian dan jelas tampak penjabarannya di dalam pertimbangan hakim. Sedemikian rupa jelasnya diuraikan secara rinci dan sistematis, persesuaian keterangan saksi dengan alat bukti lain, yaitu jika yang diajukan penuntut umum dalam persidangan merupakan keterangan saksi diikuti dengan alat bukti lain, baik berupa ahli, surat atau

5 R. Tresna, Peradilan di Indonesia dari Abad ke Abad, W. Versluys N. V, Amsterdam, Jakarta, 1957, h. 72, dalam Andi Hamzah, Hukum Acara Pidana Indonesia, Sinar Grafika, Jakarta, 2008, hlm. 120.

Andi Hamzah, Hukum Acara Pidana Indonesia, Sinar Grafika, Jakarta, 2008, hlm. 256.

Muhadar, Edi Abdullah, Husni Thamrin, supra note 2., hlm. 3.

Ibid.

Yahya harahap. supra note l, hlm. 183. 
petunjuk, hakim harus meneliti dengan sungguh-sungguh saling persesuaian maupun pertentangan antara keterangan saksi dengan alat bukti yang lain, serta alasan saksi memberi keterangan tertentu, yaitu hakim harus mencari alasan saksi kenapa memberikan keterangan seperti itu. Dengan mengetahui alasan saksi yang pasti, akan memberikan gambaran yang jelas bagi hakim tentang keadaan yang diterangkan saksi. ${ }^{10}$

Ada beberapa putusan pengadilan berkenaan dengan unsur ini. Pertama, Putusan Hoge Raad 25 Juni 1928, di mana diberikan pertimbangan bahwa, "suatu keterangan itu adalah palsu, jika sebahagian dari keterangan itu adalah tidak benar, walaupun yang sebagian ini mempunyai arti yang tidak demikian pentingnya, ...". Kedua, Putusan Hoge Raad, 4 April 1938, di mana diberikan pertimbangan bahwa, "juga apabila beberapa bagian dari suatu keterangan itu adalah tidak palsu, hakim dapat menganggap keterangan itu sebagai satu kesatuan dan menyatakan terrbukti, bahwa keterangan itu adalah palsu tanpa pembebasan untuk sebagian". Dua kutipan putusan di atas menunjukkan bahwa jika sebagian atau beberapa bagian dari keterangan yang diberikan itu tidak benar (palsu), sekalipun sebenarnya bagian yang tidak benar (palsu) itu tidak begitu penting, perbuatan itu sudah termasuk ke dalam pengertian sumpah palsu.

Ketiga, utusan Hoge Raad, 17 Juni 1889, di mana diberikan pertimbangan bahwa, suatu keterangan saksi itu dianggap belum ada, sebelum pemeriksaan saksi di persidangan itu selesai, juga apabila kesaksian itu adalah palsu. Apabila seorang saksi mencabut kembali keterangannya sebelum pemeriksaannya itu selesai, maka bagian yang dicabut kembali itu bukanlah merupakan bagian dari keterangannya, walaupun seandainya benar bahwa pencabutan kembali itu adalah sebagai akibat dari adanya peringatan bahwa ia dapat dikenakan penahanan karena memberikan keterangan di bawah sumpah secara palsu.

Terdapat beberapa faktor penyebab seorang saksi memberikan keterangan palsu di persidangan, diantaranya saksi bermaksud melindungi terdakwa, saksi bermaksud memberatkan terdakwa, saksi mendapat ancaman dari pihak lain yang tidak menginginkan perkara menjadi terang, saksi bermaksud untuk tidak melibatkan orang lain yang juga turut serta dalam tindak pidana, saksi menginginkan keterlibatan orang lain (yang sebenarnya tidak terlibat) dalam tindak pidana serta saksi berpotensi menjadi tersangka. ${ }^{11}$

Mengenai keterangan palsu, R. Soesilo menulis bahwa:

"Supaya dapat dihukum, pembuat (saksi) harus mengetahui bahwa ia memberikan suatu keterangan dengan sadar bahwa keterangan itu bertentangan dengan kenyataan dan bahwa ia memberikan keterangan palsu tersebut di atas sumpah. Suatu keterangan palsu itu menyatakan keadaan lain dari pada keadaan yang sebenarnya dengan dikehendaki (dengan sengaja)." ${ }^{12}$

Tulisan ini menggunakan pendekatan statute approach (pendekatan perundang-undangan), conceptual approach (pendekatan konsep), dan case aprroach (pendekatan kasus). Statute approach

10 Ibid, hlm. 290-29l.

11 Amir Syamsuddin, Advokat dan Tuduhan Keterangan Palsu http://nasional.kompas.com/read/2015/01/28/ 14341241/Advokat.dan.Tuduhan.Keterangan.Palsu, diakses tanggal 28 Oktober 2017.

12 R. Soesilo, Kitab Undang-Undang Hukum Pidana (KUHP) Serta Komentar-Komentarnya Lengkap Pasal Demi Pasal, Politeia, Bogor, 1995, hlm. 183. 
adalah pendekatan yang dilakukan dengan menelaah semua undang-undang dan regulasi yang berhubungan dengan isu hukum yang sedang ditangani. ${ }^{13}$ Case approach adalah pendekatan yang dilakukan dengan cara menelaah terhadap kasus-kasus yang berkaitan dengan isu yang dihadapi dan telah menjadi putusan pengadilan. ${ }^{14}$ Conceptual approach adalah pendekatan yang berawal dari pandangan-pandangan dan doktrin-doktrin yang berkembang di dalam ilmu hukum. Dengan mempelajari hal tersebut, peneliti akan menemukan ide yang melahirkan pengertianpengertian hukum, konsep-konsep hukum, dan asas-asas hukum yang relevan dengan isu yang dihadapi. ${ }^{15}$

\section{PENYIDIKAN KEPOLISIAN TERHADAP KASUS KETERANGAN PALSU DI DEPAN PERSIDANGAN PENGADILAN}

\section{A. Kewenangan Penyidik Kepolisian}

Tujuan dari dibuatnya suatu hukum adalah untuk mengatur kehidupan dalam masyarakat di suatu negara dengan cara memaksa anggota masyarakat untuk mematuhi hukum. Jika hukum tidak dipatuhi, untuk mempertahankan hukum dan hak dalam negara hukum yaitu dengan jalan beracara, pejabat-pejabat hukum tertentu berhak menentukan hukum secara konkrit, yaitu hakim dan pengadilan. ${ }^{16}$

Untuk melaksanakan hukum pidana diperlukan cara-cara yang harus ditempuh agar ketertiban hukum dalam masyarakat dapat ditegakkan. Cara itu disebut sebagai hukum acara pidana. Tujuan hukum acara pidana antara lain dapat dibaca dalam Pedoman Pelaksanaan KUHAP yang dikeluarkan oleh Menteri Kehakiman adalah untuk mencari dan mendapatkan atau setidaknya mendekati kebenaran materiil. Artinya kebenaran yang selengkap-lengkapnya dari suatu perkara pidana dengan menerapkan ketentuan hukum acara pidana secara jujur dan tepat dengan tujuan untuk mencari siapakah pelaku yang dapat didakwakan melakukan suatu pelangaran hukum dan selanjutnya meminta pemeriksaan dan putusan dari pengadilan guna menemukan apakah terbukti bahwa suatu tindak pidana telah dilakukan dan apakah orang yang didakwa itu dapat dipersalahkan. ${ }^{17}$

Proses peradilan pidana menyangkut kegiatan-kegiatan dari badan peradilan pidana yang berjalan menurut tahapan tertentu. Tiap tahapan tersebut menunjukkan satu rangkaian kesatuan utuh sebagai sistem roda berjalan. Tahap atau periodesasi peradilan pidana dimulai dari tahap penyidikan, penuntutan, pemeriksaan di muka pengadilan hingga pelaksanaan

13 Peter Mahmud Marzuki, Penelitian Hukum, Edisi Revisi Cetakan ke-12, Prenadamedia Group, Jakarta, 2016, hlm. 133.

$14 \quad$ Ibid, hlm. 134.

15 Ibid., hlm. 135-136.

16 Yusti Probowati Rahayu, Dibalik Putusan Hakim (kajian psikologi hukum dalam perkara pidana), Srikandi, Surabaya, 2005, hlm. 17.

17 Andi Hamzah, supra note 1., hlm. 8. 
keputusan pengadilan. ${ }^{18}$ Kegiatan tersebut dilaksanakan oleh masing-masing badan peradilan pidana sesuai dengan tugas dan wewenangnya berdasarkan ketentuan yang berlaku, diantaranya kepolisian, kejaksaan, pengadilan dan lembaga pemasyarakatan.

Penyidikan merupakan suatu tahap terpenting dalam kerangka hukum acara pidana di Indonesia karena dalam tahap ini pihak penyidik berupaya mengungkapkan fakta-fakta dan bukti-bukti atas terjadinya suatu tindak pidana serta menemukan tersangka pelaku tindak pidana tersebut. Di dalam konsideran huruf b Undang-Undang Nomor 2 Tahun 2002 tentang Kepolisian Negara Republik Indonesia (UU Kepolisian) ditegaskan bahwa pemeliharaan keamanan dalam negeri melalui upaya penyelenggaraan fungsi kepolisian yang meliputi pemeliharaan keamanan dan ketertiban masyarakat, penegakkan hukum, perlindungan, pengayoman, dan pelayanan kepada masyarakat dilakukan oleh Kepolisian Negara Republik Indonesia selaku alat negara yang dibantu masyarakat dengan menjunjung tinggi hak asasi manusia. ${ }^{19}$

Dalam rangka menyelenggarakan tugas sebagai penegak hukum khususnya dalam proses pidana, kepolisian memiliki kewenangan sebagai penyelidik dan penyidik. KUHAP membedakan antara penyelidik dan penyidik. Pengertian penyelidikan menurut Pasal 1 angka 5 KUHAP yaitu tindakan penyelidik untuk mencari dan menemukan suatu peristiwa yang diduga sebagai tindak pidana untuk menentukan dapat atau tidaknya dilakukan penyidikan menurut cara yang diatur dalam KUHAP. Sedangkan penyidikan menurut Pasal 1 angka 2 KUHAP, yaitu tindakan penyidik dalam hal dan menurut cara yang diatur dalam undang-undang ini untuk mencari serta mengumpulkan bukti yang membuat terang tentang tindak pidana yang terjadi dan untuk menemukan tersangkanya.

Pasal 7 ayat (l) KUHAP mengatur bahwa Penyidik Polri karena kewajibannya mempunyai wewenang menerima laporan atau pengaduan dari seorang tentang adanya tindak pidana, melakukan tindakan pertama pada saat di tempat kejadian, menyuruh berhenti seorang tersangka dan memeriksa tanda pengenal diri tersangka, melakukan penangkapan, penahanan, penggeledahan dan penyitaan, melakukan pemeriksaan dan penyitaan surat, mengambil sidik jari dan memotret seorang, memanggil orang untuk didengar dan diperiksa sebagai tersangka atau saksi, mendatangkan orang ahli yang diperlukan dalam hubungannya dengan pemeriksaan perkara, mengadakan penghentian penyidikan, mengadakan tindakan lain menurut hukum yang bertanggung jawab.

Pasal 16 ayat (1) UU Kepolisian mengatur bahwa dalam rangka menyelenggarakan tugas sebagaimana dimaksud dalam Pasal 13 dan 14 dalam proses pidana, Kepolisian Negara Republik Indonesia berwenang untuk melakukan penangkapan, penahanan, penggeledahan, dan penyitaan, melarang setiap orang meninggalkan atau memasuki tempat kejadian perkara untuk kepentingan penyidikan, membawa dan menghadapkan orang kepada penyidik dalam rangka penyidikan, menyuruh berhenti orang yang dicurigai dan menanyakan serta memeriksa tanda

Kadri Husin \& Budi Rizki Husin, Sistem Peradilan Pidana di Indonesia, Sinar Grafika, Jakarta, 2016, hlm. 91.

19 Ruslan Renggong, Hukum Acara Pidana Memahami Perlindungan HAM dalam Proses Penahanan di Indonesia, Prenadamedia Group, Jakarta, 2014, hlm. 206. 
pengenal diri, melakukan pemeriksaan dan penyitaan surat, memanggil orang untuk didengar dan diperiksa sebagai tersangka atau saksi, mendatangkan orang ahli yang diperlukan dalam hubungannya dengan pemeriksaan perkara, mengadakan penghentian penyidikan, menyerahkan berkas perkara kepada penuntut umum, mengajukan permintaan secara langsung kepada pejabat imigrasi yang berwenang di tempat pemeriksaan imigrasi dalam keadaan mendesak atau mendadak untuk mencegah atau menangkal orang yang disangka melakukan tindak pidana, memberi petunjuk dan bantuan penyidikan kepada penyidik pegawai negeri sipil serta menerima hasil penyidikan penyidik pegawai negeri sipil untuk diserahkan kepada penuntut umum dan mengadakan tindakan lain menurut hukum yang bertanggung jawab.

Berdasarkan dua pasal di atas, menunjukkan bahwa penyidikan merupakan tugas dari kepolisian. Termasuk dalam penyelesaian suatu perkara keterangan palsu di bawah sumpah, apabila terdapat laporan mengenai dugaan suatu tindak pidana memberikan keterangan palsu di bawah sumpah dalam suatu persidangan, maka penyidik berhak untuk melakukan penyidikan termasuk melakukan tindakan yang bersifat memaksa lainnya demi mendapatkan bukti yang membuat terang tentang suatu tindak pidana yang terjadi.

Memberi keterangan palsu dipandang sebagai kesalahan yang sangat buruk. Hal ini dianggap merusak kewajiban terhadap kesetiaan umum atau sebagai kedustaan terhadap masyarakat, sebagai ketidakjujuran terhadap Tuhan, demikian pula terhadap hakim yang menjalankan peradilan atas nama Tuhan. ${ }^{20}$ Apa yang diharapkan oleh undang-undang dari seorang saksi keterangan yang sesungguhnya. Akan tetapi, saksi sebagai manusia biasa mungkin dipengaruhi oleh motivasi yang sulit diketahui hakim. Mungkin saksi mempunyai kepentingan pribadi dalam perkara yang sedang diperiksa, sehingga membuat dia cenderung memberi keterangan palsu. Bagaimanapun pandainya menyusun kata-kata bohong dan palsu, sering kebohongan dan kepalsuan itu tidak dapat disembunyikan. ${ }^{21}$

\section{B. Analisis Putusan Perkara Keterangan Palsu di Bawah Sumpah}

Berikut adalah contoh kasus keterangan palsu di persidangan yang proses penyelesaiannya menggunakan Pasal 174 KUHAP sebagai alasan untuk menghentikan penyidikan atau membebaskan terdakwa dari hukuman dan kasus yang mengabaikan Pasal 174 KUHAP untuk memberikan pidana bagi terdakwa keterangan palsu.

\section{Putusan sela dalam kasus terdakwa Gerson Tanuab}

Kasus terdakwa Gerson Tanuab adalah terkait dengan Putusan Sela Nomor 158/Pid.B/2015/PN.KPG dan Putusan Nomor 158/Pid.B/2015/PN.KPG. Putusan tersebut menyatakan bahwa terdakwa Gerson Tanuab pada hari Selasa, 22 Oktober 2013 pada waktu yang tidak dapat diingat secara pasti lagi sekitar pukul 15.00 WITA atau setidak-tidaknya pada waktu-waktu lain dalam bulan Oktober 2013, bertempat di ruang sidang Pengadilan Negeri Klas 1 A Kupang di Kupang atau setidak-tidaknya pada suatu tempat lain masih termasuk dalam daerah hukum Pengadilan Negeri

20 R. Soesilo, supra note 12. hlm. 183.

2l M. Yahya Harahap, supra note 1, hlm. 195. 
Kupang, dalam keadaan di mana undang-undang menentukan supaya memberikan keterangan di atas sumpah atau mengadakan akibat hukum kepada keterangan yang demikian, dengan sengaja memberikan keterangan palsu di atas sumpah, baik dengan lisan atau tulisan, secara pribadi maupun oleh kuasanya yang khusus ditunjuk untuk itu, perbuatan terdakwa dilakukan dengan cara sebagai berikut:

Bahwa pada waktu dan tempat sebagaimana dimaksud di atas, terdakwa yang saat itu dihadirkan untuk dimintai keterangan sebagai saksi dan di bawah sumpah dalam perkara perdata Nomor 29/pdt.G/2013/PN KPG, di mana terdakwa dihadirkan untuk menjadi saksi dari pihak penggugat yakni saksi Rudi Ebenhaeser Oematan yang menggugat saksi Ny. Greetje Jeane Koamesah Rondo (sebagai tergugat I) dan Badan Pertanahan Nasional (BPN) Kota Kupang sebagai (tergugat II), serta Jaya Suprana sebagai (tergugat III), di mana sebelum terdakwa memberikan keterangannya sebagai saksi dalam persidangan perdata dimaksud, terdakwa memberikan keterangan sebagai saksi di Pengadilan Negeri Kupang terlebih dahulu diambil sumpah berdasarkan agama Kristen Protestan.

Bahwa terdakwa dihadirkan sebagai saksi dalam persidangan perkara perdata Nomor 29/pdt.G/2013/PN KPG, sehubungan dengan terdakwa sebagai petugas juru sita Pengadilan Negeri Kupang yang melaksanakan eksekusi atas objek tanah berdasarkan Putusan Pengadilan Negeri Nomor 54/PDT/G/1981 yang dalam amar putusan pada angka 4 menyatakan pada pokoknya agar pihak tergugat I menyerahkan kembali tanah yang berdasarkan hasil pemeriksaan setempat dengan pengukuran/pemetaan pada Petak A dan seterusnya. Selanjutnya pelaksanaan ekesusi tersebut dituangkan dalam berita acara eksekusi sebagaimana dalam berita acara penyerahan dari tergugat I kepada terdakwa selaku petugas juru sita Nomor 54/BA.Pdt.G/1981/PN.KPG tanggal 10 Desember 1991 dan Berita Acara penyerahan Tanah dari terdakwa selaku Juru sita kepada penggugat Nomor 54/BA Pdt.G/1981/PN.KPG tanggal 28 Januari 1992.

Bahwa tanah objek sengketa yang dimaksud dalam proses persidangan perkara perdata atas permintaan Majelis Hakim Pengadilan Negeri Kupang telah dilakukan pemeriksan setempat untuk menentukan luas dan batas-batas tanah dan akhirnya lokasi tanah tersebut terbagi menjadi Lokasi A, B, C dan D dengan luas seluruhnya 43615 M2, sedangkan yang menjadi objek sengketa dalam perkara perdata nomor : 54/PDT/G/1981 adalah tanah petak A sebagaimana tertuang dalam amar putusan perkara Perdata Nomor : 54/PDT/G/1981 adalah tanah dalam lokasi Petak A dengan luas 5033 M 2.

Bahwa terdakwa sebagai saksi dari pihak penggugat yang saat itu memberikan keterangan setelah saksi Eliazer Benggu (saksi ke I) didengar keterangannya juga dari pihak penggugat, dalam keterangan terdakwa telah disampaikan fakta pelaksanaan eksekusi atas tanah berdasarkan putusan perkara perdata Nomor 54/PDT/G/1981 tanggal 10 Desember 1991 tidak sesuai dengan isi putusan tersebut dan berbeda dengan berita acara penyerahan yang dibuatkan oleh terdakwa sendiri selaku petugas juru sita pada Pengadilan Negeri Klas I Kupang sebagaimana berita acara Nomor 54/BA.Pdt.G/1981/PN.KPG tanggal 10 Desember 1991 dan Berita Acara penyerahan Tanah Nomor 54/BA Pdt.G/1981/PN.KPG tanggal 28 Januari 1992.

Terdakwa sebagai pejabat Pengadilan Negeri Kupang yang melakukan eksekusi objek sengketa dalam perkara perdata nomor 54 tahun 1981, selanjutnya dihadirkan sebagai saksi 
dalam perkara perdata Nomor 29/PDT/G/2013/PN KPG dibawah sumpah memberikan keterangan yang isinya: "Bahwa pada saat itu yang di serahkan secara sukarela adalah 3 (tiga) bidang tanah yaitu petak A, C, D. Sedangkan petak B ditunda penyerahannya atas permintaan tergugat I karena pada saat itu tergugat I adalah anggota DPRD ", keterangan terdakwa tersebut selanjutnya termuat dalam putusan majelis hakim halaman 32 pada pointer 3 kemudian menjadi pertimbangan hukum majelis hakim dalam putusan perkara perdata Nomor 29/PDT/G/2013/PN KPG sebagaimana terurai dalam halaman 48 paragraf kedua dan halaman 49 paragraf pertama. Perbuatan terdakwa sebagaimana diatur dan diancam pidana dalam Pasal 242 KUHP.

Pada awal kasus keterangan palsu ini, Penasihat Hukum Terdakwa mengajukan eksepsi atas dakwaan Penuntut Umum di mana menurut pihak terdakwa isi surat dakwaan tersebut tidak memenuhi unsur Pasal 143 ayat (2) huruf b mengenai surat dakwaan yang harus diuraikan secara cermat, jelas dan lengkap. Bahwa menurut Penasihat Hukum Terdakwa, setelah mencermati isi surat dakwaan dari Penuntut Umum, ternyata terdakwa didakwa telah melakukan perbuatan sebagaimana diatur dan diancam pidana dalam pasal 242 KUHP di mana Pasal 242 KUHP menentukan bahwa agar seorang saksi di persidangan yang memberikan keterangan palsu dapat dihukum, harus memenuhi syarat formal dan syarat materiil. Syarat formalnya adalah bahwa seorang saksi dipersidangan dituduh telah memberikan keterangan palsu, harus ada penetapan hakim sidang dan syarat materiilnya adalah harus atas sumpah yakni bahwa keterangan itu diwajibkan menurut undang-undang yang dapat menentukan akibat hukum pada keterangan tersebut, dan keterangannya harus palsu dan kepalsuannya diketahui oleh saksi.

Bahwa dalam praktek peradilan, seorang hakim mempunyai hak untuk menilai keterangan saksi sebagai salah satu alat bukti. Dalam kaitan dengan keterangan palsu, secara teknis seorang hakim memiliki keyakinan bahwa saksi tersebut berbohong, hakim ketua akan men-skorsing sidang untuk bermusyawarah dengan para hakim anggota, dan jika musyawarah tersebut mencapai kesepakatan, majelis hakim akan mengeluarkan penetapan. Dengan demikian, tidak diperlukan adanya suatu laporan pidana terlebih dahulu sebelum majelis hakim mengeluarkan penetapan untuk menahan saksi yang diduga memberikan keterangan palsu dibawah sumpah tersebut.

Bahwa persidangan di mana terdakwa memberikan kesaksian adalah perkara perdata tidak berlaku ketentuan Pasal 174 KUHAP sehingga tidak ada penetapan Majelis Hakim Pengadilan Negeri Kupang yang memeriksa dan mengadili perkara Nomor 29/Pdt.G/2013/PN.KPG yang menetapkan bahwa saksi Gerson Tanuab telah memberikan keterangan palsu. Kemudian, berdasarkan keberatan penasihat hukum terdakwa dan jawaban enuntut umum, majelis hakim berpendapat bahwa "sangkaan atas sumpah palsu" terjadi ketika suatu perkara diperiksa di persidangan, sehingga terhadap keterangan seorang saksi yang dinilai palsu setelah selesai pemeriksaan suatu perkara tidak dapat dilakukan penuntutan dengan prosedur konvensional, dalam hal ini majelis hakim dapat menerima pendapat penasihat hukum terdakwa. 
Bertolak dari paparan di atas, menurut pendapat majelis hakim, bahwa mengajukan terdakwa ke persidangan dengan dakwaan sumpah palsu sebagaimana didakwakan kepada terdakwa dalam perkara in casu tidak sejalan dengan filosofi, maksud dan tujuan ketentuan Pasal 174 KUHAP jo Pasal 242 KUHP, juga secara tersirat penuntut umum dalam tanggapannya mengutip beberapa ketentuan tentang sumpah palsu, bahwa " kejahatan sumpah palsu dipandang sempurna apabila saksi itu tetap pada keteranganya kendati sudah diperingatkan oleh majelis hakim (vide pasal 174 KUHAP)" karena kata-kata bahwa saksi menyatakan tetap pada keterangannya setelah diperingatkan oleh hakim memberikan gambaran bahwa sumpah palsu merupakan sangkaan majelis hakim setelah mendengar keterangan saksi di persidangan sehingga hal ini berarti prosedur pengajuan terdakwa dengan dakwaan sumpah palsu dimulai pada saat persidangan dengan sinyalemen ada keterangan yang tidak benar yang diberikan oleh saksi di bawah sumpah dan majelis hakim yang memeriksa perkara tersebut telah memberikan peringatan kepada saksi tersebut, dan setelah adanya sangkaan sumpah palsu tersebut baru kemudian berita acara pemeriksaan saksi dimaksud oleh majelis hakim diberikan kepada penuntut umum dalam perkara tersebut untuk diteruskan kepada proses penyidikan. Dengan demikian, majelis hakim berpendapat bahwa keberatan Penasihat Hukum Terdakwa berdasarkan hukum sehingga haruslah dinyatakan diterima, dan dakwaan Jaksa Penuntut Umum patut dinyatakan batal demi hukum.

Atas pertimbangan tersebut, hakim menerima keberatan penasihat hukum terdakwa dan menyatakan perkara tersebut tidak dapat dilanjutkan dan memerintahkan agar mengembalikan berkas perkara kepada penuntut umum. Kemudian, atas putusan sela tersebut, penuntut umum mengajukan banding ke Pengadilan Tinggi Kupang Nomor 116/Pid/2015/PT.KPG yang dalam putusan hakim dijatuhkan putusan yang membatalkan putusan sela Nomor 158/Pid.B/2015/PN Kpg. Putusan tersebut memerintahkan Pengadilan Negeri Kupang agar melanjutkan pemeriksaan kasus pidana keterangan palsu atas nama terdakwa Gerson Tanuab dilanjutkan.

Kemudian Pengadilan Negeri Kupang melanjutkan pemeriksaan dan persidangan kasus pidana keterangan palsu atas nama Gerson Tanuab dengan dakwaan penuntut umum sebagai berikut:

Bahwa terdakwa Gerson Tanuab pada hari Selasa tanggal 22 Oktober 2013 pada waktu yang tidak dapat diingat secara pasti lagi sekitar pukul 15.00 WITA atau setidak-tidaknya pada waktu-waktu lain dalam bulan Oktober 2013, bertempat di ruang sidang Pengadilan Negeri Klas 1 A Kupang di Kupang atau setidak-tidaknya pada suatu tempat lain masih termasuk dalam daerah hukum Pengadilan Negeri Kupang, dalam keadaan dimana undang-undang menentukan supaya memberikan keterangan diatas sumpah atau mengadakan akibat hukum kepada keterangan yang demikian, dengan sengaja memberikan keterangan palsu di atas sumpah, baik dengan lisan atau tulisan, secara pribadi maupun oleh kuasanya yang khusus ditunjuk untuk itu.

Bahwa pada waktu dan tempat sebagaimana dimaksud di atas, terdakwa yang saat itu dihadirkan untuk dimintai keterangan sebagai saksi dan di bawah sumpah dalam perkara perdata Nomor 29/pdt.G/2013/PN KPG, di mana terdakwa dihadirkan untuk menjadi saksi dari pihak penggugat yakni saksi Rudi Ebenhaeser Oematan yang menggugat saksi Ny. Greetje Jeane Koamesah Rondo (sebagai tergugat I) dan BPN Kota Kupang sebagai (tergugat II), serta Jaya Suprana sebagai (tergugat III), di mana sebelum terdakwa memberikan keterangannya sebagai saksi dalam persidangan perdata, terdakwa 
memberikan keterangan sebagai saksi di Pengadilan Negeri Kupang terlebih dahulu diambil sumpah menurut agama Kristen Protestan.

Bahwa terdakwa dihadirkan sebagai saksi dalam persidangan perdata Nomor : 29/pdt.G/2013/PN KPG, sehubungan dengan terdakwa sebagai petugas juru sita Pengadilan Negeri Kupang yang melaksanakan eksekusi atas objek tanah berdasarkan Putusan Pengadilan Negeri Nomor : 54/PDT/G/1981 yang dalam amar putusan pada angka 4 (empat) menyatakan pada pokoknya : agar pihak tergugat I menyerahkan kembali tanah yang berdasarkan hasil pemeriksaan setempat dengan pengukuran / pemetaan pada Petak A dan seterusnya?.. selanjutnya pelaksanaan ekesusi tersebut di tuangkan dalam Berita acara eksekusi sebagaimana dalam berita acara penyerahan dari tergugat I kepada terdakwa selaku petugas juru sita Nomor: 54/BA.Pdt.G/1981/PN.KPG tanggal 10 Desember 1991 dan Berita Acara penyerahan Tanah dari terdakwa selaku Juru sita kepada penggugat Nomor : 54/BA Pdt.G/1981/PN.KPG tanggal 28 Januari 1992.

Bahwa tanah objek sengketa dimaksud dalam proses persidangan perdata atas permintaan Majelis Hakim Pengadilan Negeri Kupang telah dilakukan pemeriksan setempat untuk menentukan luas dan batas-batas tanah dan akhirnya lokasi tanah tersebut terbagi menjadi Lokasi A, B, C dan D dengan luas seluruhnya 43615 M2, sedangkan yang menjadi objek sengketa dalam perkara perdata Nomor 54/PDT/G/1981 adalah tanah petak A sebagaimana tertuang dalam amar putusan Perdata Nomor 54/PDT/G/1981 adalah tanah dalam lokasi petak A dengan luas 5033 M 2.

Bahwa terdakwa sebagai saksi dari pihak penggugat yang saat itu memberikan keterangan setelah saksi ELIAZER BENGGU (saksi ke I) didengar keterangan juga dari pihak penggugat, dalam keterangannya terdakwa telah menyampaikan fakta pelaksanaan eksekusi atas tanah berdasarkan Putusan perdata Nomor : 54/PDT/G/1981 tanggal 10 Desember 1991 tidak berkesesuaian dengan isi dari putusan tersebut dan berbeda dengan Berita acara penyerahan yang di buatkan oleh terdakwa sendiri selaku petugas juru sita pada Pengadilan Negeri Klas I Kupang sebagaimana berita acara Nomor : 54/BA.Pdt.G/1981/PN.KPG tanggal 10 Desember 1991 dan Berita Acara penyerahan Tanah Nomor : 54/BA Pdt.G/1981/PN.KPG tanggal 28 Januari 1992.

Terdakwa sebagai pejabat Pengadilan Negeri Kupang yang melakukan eksekusi objek sengketa dalam perkara Perdata Nomor 54 tahun 1981, selanjutnya dihadirkan sebagai saksi dalam perkara Perdata Nomor 29/PDT/G/2013/PN KPG di bawah sumpah memberikan keterangan yang isinya:

"Bahwa pada saat itu yang di serahkan secara sukarela adalah 3 (tiga) bidang tanah yaitu petak A,C,D sedangkan petak B ditunda penyerahannya atas permintaan tergugat I karena pada saat itu tergugat I adalah anggota DPRD.“

Keterangan terdakwa tersebut selanjutnya termuat dalam putusan Majelis hakim halaman 32 pada pointer 3 kemudian menjadi pertimbangan hukum majelis hakim dalam putusan perkara perdata Nomor 29/PDT/G/2013/PN KPG sebagaimana terurai dalam halaman 48 paragraf ke 2 (dua) dan halaman 49 paragraf pertama. Perbuatan terdakwa sebagaimana diatur dan diancam pidana dalam Pasal 242 KUHP.

Kemudian, berdasarkan fakta hukum dan dakwaan yang didakwakan oleh penuntut umum, yaitu Pasal 242 KUHP dan pertimbangan majelis hakim serta berdasarkan keterangan saksi dan bukti di persidangan, maka majelis hakim berpendapat bahwa keseluruhan unsurunsur di dalam Pasal 242 KUHP terpenuhi dan terbukti sehingga terdakwa dinyatakan terbukti 
secara sah dan meyakinkan memberikan keterangan palsu di atas sumpah sebagaimana dalam dakwaan tunggal penuntut umum. Terdakwa dijatuhkan pidana penjara selama tiga tahun.

Dilihat dari putusan tersebut, di mana pada awalnya para saksi memberikan keterangan palsu di depan persidangan tetapi tidak dinyatakan atau ditetapkan oleh hakim bahwa mereka telah memberikan keterangan palsu sehingga tidak ditahan dan dituntut dengan dakwaan keterangan palsu di bawah sumpah. Setelah perkara semula di mana saksi tersebut memberikan keterangan selesai diputus barulah saksi dilaporkan ke kepolisian untuk disidik dengan perkara keterangan palsu. Kemudian dalam penyelesaiannya di pengadilan terdapat perbedaan pandangan antara para pihak di mana pihak terdakwa menganggap bahwa sesuai Pasal 174 KUHAP, seorang saksi tidak dapat lagi dilaporkan dan dituntut dengan dakwaan keterangan palsu apabila tidak ada penetapan dari hakim pada saat persidangan tersebut berlangsung, sedangkan menurut pandangan penuntut umum bahwa meskipun hakim tidak menetapkan saksi telah memberikan keterangan palsu, saksi tersebut tetap dapat dilaporkan di kepolisian dan dituntut dengan dakwaan keterangan palsu.

Pasal 174 KUHAP menyebutkan bahwa setelah penuntut umum menerima berita acara sidang yang ditandatangani oleh Hakim Ketua Majelis, selanjutnya diselesaikan menurut ketentuan undang-undang. Hal ini berlaku apabila saksi ditetapkan oleh hakim telah memberikan keterangan palsu di persidangan. Pasal 174 tidak menyebutkan mengenai prosedur apabila hakim tidak menetapkan saksi tersebut telah memberikan keterangan palsu dan di kemudian hari diketahui bahwa saksi tersebut sebenarnya telah memberikan keterangan palsu sehingga menimbulkan kerugian bagi terdakwa. Hal inilah yang menimbulkan pandangan apabila tidak ada penetapan dari hakim bahwa seorang saksi telah memberikan keterangan palsu maka saksi tersebut tidak dapat dilaporkan dan penyidik tidak berwenang melakukan penyidikan karena yang dapat menetapkan seorang saksi telah memberikan keterangan palsu hanyalah hakim, serta Pasal 242 KUHP hanya berlaku apabila ada penetapan hakim bahwa seorang saksi telah memberikan keterangan palsu. Seperti yang telah dijelaskan sebelumnya, bahwa dalam praktek peradilan berkembang perbedaan pendapat mengenai penerapan Pasal 174 ayat (3) berkenaan dengan penyidikan perkara saksi palsu. ${ }^{22}$

\section{Tidak melalui prosedur penyidikan oleh kepolisian.}

Pendapat ini menafsirkan bahwa berita acara sidang dibuat panitera yang ditandatangani panitera dan ketua sidang. Sebagaimana dijelaskan Pasal 174 ayat (3), dianggap cukup sebagai berita acara penyidikan untuk dijadikan dasar bagi penuntut umum melakukan penuntutan terhadap saksi yang memberikan keterangan palsu di persidangan tidak perlu lagi melaui proses laporan dan penyidikan di kepolisian. Dengan kata lain dasar proses pemeriksaan sidang pengadilan atas perkara sumpah palsu yang diatur dalam Pasal 174 ayat (3) adalah berita acara sidang yang dibuat oleh panitera.

Berita acara sidang yang dibuat oleh panitera kemudian segera dilimpahkan ke penuntut umum agar dibuatkan surat dakwaan. Penuntut umum dapat melakukan penyidikan lanjutan

22 Ibid, hlm. 197. 
apabila kurangnya bukti untuk merumuskan surat dakwaan. Selanjutnya penuntut umum harus segera melimpahkan perkara tersebut ke pengadilan agar segera diproses. Hal ini juga dilakukan dengan maksud agar proses penyelesaian perkara dengan asas cepat, sederhana dan biaya ringan terpenuhi. ${ }^{23}$

Pendapat ini dikemukakan apabila yang terjadi adalah ketika sedang berlangsung persidangan, hakim menetapkan bahwa saksi yang memberikan keterangan telah memberikan keterangan palsu. Apabila setelah kasus semula telah diputus dan di kemudian hari baru diketahui bahwa saksi telah memberikan keterangan palsu maka penyidik tetap berwenang untuk melakukan penyidikan atas dugaan melakukan tindak pidana yang dirumuskan dalam Pasal 242 KUHP. Beberapa kasus terjadi di mana seorang saksi memberikan keterangan palsu di depan persidangan namun baru diketahui di kemudian hari setelah perkara semula diputus, dan saksi tersebut tetap dapat disidik oleh penyidik hingga akhirnya diputus bersalah dan dijatuhi pidana oleh hakim.

Dengan tidak adanya penetapan dari hakim bahwa seorang saksi telah memberikan keterangan palsu bukan berarti saksi tersebut tidak berbuat tindak pidana sebagaimana dalam Pasal 242 KUHP. Suatu keterangan palsu yang diberikan oleh seorang saksi akan mempengaruhi jalannya persidangan atau mempengaruhi pengambilan keputusan oleh hakim dan mempengaruhi nasib seorang terdakwa. Seperti pada kasus keterangan palsu pada putusan Mahkamah Agung Nomor 499K/Pid./2013, atas pertimbangan hakim terdakwa dijatuhi pidana karena memenuhi unsur-unsur dalam Pasal 242 ayat (2), yaitu keterangan palsu di bawah sumpah yang diberikan oleh terdakwa sebagai saksi telah mengakibatkan kerugian bagi pihak lain. Demikian juga pada putusan kasus keterangan palsu Nomor 158/Pid.B/2015.PN.KPG terdakwa dijatuhi putusan pidana oleh majelis hakim karena tindakannya sebagai saksi telah memenuhi unsur-unsur dalam Pasal 242 ayat (1) KUHP.

Dengan demikian, apabila di dalam suatu persidangan seorang saksi diketahui telah memberikan keterangan palsu maka berlaku proses penyelesaian perkara keterangan palsu di bawah sumpah sesuai dengan ketentuan Pasal 174 KUHAP, yaitu hakim menetapkan saksi tersebut telah memberikan keterangan palsu serta memberi perintah agar saksi tersebut ditahan. Atas hal tersebut, panitera membuat Berita Acara Pemeriksaan sidang yang ditandatangani oleh hakim ketua sidang dan panitera untuk diserahkan kepada penuntut umum. Kemudian penuntut umum membuat surat dakwaan untuk menuntut terdakwa berdasarkan berita acara sidang tersebut dan kemudian melimpahkan perkara tersebut ke pengadilan untuk dilakukan pemeriksaan di persidangan.

\section{Melalui prosedur penyidikan}

Pendapat ini bertentangan dengan pendapat pertama karena berdasarkan Pasal 6 KUHAP, yang berfungsi dan berwenang melakukan penyidikan tindak pidana adalah pejabat kepolisian. Demikian dalam Pasal 8 KUHAP, yang berfungsi dan berwenang membuat berita acara perkara pidana sesuai dengan bentuk dan isi yang ditentukan Pasal 75 KUHAP adalah penyidik, dalam

23 Ibid. 
hal ini pejabat kepolisian. Berita acara sidang yang dibuat oleh panitera dianggap tidak lengkap dan tidak sesuai dengan yang ditentukan dalam Pasal 75 KUHAP. Berita acara sidang yang dibuat oleh panitera hanya memuat tentang keterangan saksi dan alasan persangkaan bahwa keterangan saksi tersebut palsu. ${ }^{24}$

Sejauh ini dalam proses penyelesaian perkara tindak pidana memberikan keterangan palsu di bawah sumpah, meskipun seorang saksi tidak ditetapkan oleh hakim bahwa ia telah memberikan keterangan palsu, kemudian di dalam proses pemeriksaan di pengadilan para penasihat hukum terdakwa mengajukan dalil-dalil mengenai syarat formil dari Pasal 242 KUHP (keberlakuan Pasal 174 KUHAP). Serta menyatakan bahwa proses penyelesaiannya tidak melalui laporan di kepolisian, tanpa mempertimbangkan Pasal 174 KUHAP, hakim tetap menjatuhkan putusan yang menyatakan bahwa terdakwa terbukti secara sah dan meyakinkan telah melakukan tindak pidana memberikan keterangan palsu di bawah sumpah sehingga ia harus mempertanggungjawabkan tindakannya tersebut. Dengan demikian Pasal 174 KUHAP tidak selalu berlaku dan dipertimbangkan oleh hakim apabila seorang saksi yang memberikan keterangan palsu diproses melalui laporan di kepolisian terlebih dahulu. Prosedur penyelesaian perkara keterangan palsu sesuai dengan Pasal 174 KUHAP hanya mutlak berlaku apabila di dalam persidangan seorang saksi ditetapkan oleh hakim telah memberikan keterangan palsu.

Perbedaan pendapat dalam penanganan perkara keterangan palsu di bawah sumpah ini telah dijawab oleh Mahkamah Agung dalam putusan Nomor 2514/Pid./2007 tanggal 31 Maret 2008. Ada tiga pertimbangan hukum oleh majelis hakim kasasi, yaitu keterangan palsu yang diberikan oleh seorang saksi tidak selalu dapat diketahui pada saat itu juga. Dalam menuntut seseorang atas dasar keterangan palsu tidak mutlak harus melalui perintah ketua majelis hakim. Sebagaimana ditentukan dalam Pasal 174 KUHAP serta ketentuan tersebut bukan satu-satunya jalan untuk menuntut seorang saksi yang diduga telah memberikan keterangan palsu atas dasar sumpah.

Penyelesaian kasus keterangan palsu di bawah sumpah yang melalui laporan di kepolisian terlebih dahulu, proses penyelesaiannya sesuai dengan proses penyelesaian perkara pidana yang diatur dalam KUHAP, yakni dimulai dengan adanya tindak pidana memberikan keterangan palsu di bawah sumpah yang dilakukan oleh seorang saksi pada suatu persidangan pengadilan. Akan tetapi tidak ditetapkan oleh hakim bahwa saksi tersebut telah memberikan keterangan palsu. Kemudian oleh pihak yang telah dirugikan akibat dari keterangan palsu, saksi dilaporkan ke kepolisian untuk disidik dengan dugaan memberikan keterangan palsu.

Setelah adanya laporan, penyelidik kepolisian mengumpulkan alat-alat bukti yang cukup untuk kemudian dilanjutkan dengan penyidikan oleh penyidik. Dalam perkara keterangan palsu, salah satu bukti yang diajukan biasanya adalah putusan perkara yang berisi keterangan yang diberikan oleh tersangka pada saat ia menjadi saksi. Di dalam penyidikan dilakukan pemeriksaan terhadap saksi, ahli dan tersangka. Apabila penyidik merasa berkas sudah lengkap maka berkas perkara tersebut segera dilimpahkan kepada kejaksaan untuk diperiksa lebih lanjut.

$24 \quad$ Ibid., hlm. 197-198. 
Penuntut umum memeriksa berkas perkara penyidikan kemudian membuat surat dakwaan berdasarkan hasil penyidikan yang diserahkan oleh penyidik kepolisian. Apabila penuntut umum merasa berkas tersebut belum lengkap, maka berkas tersebut dikembalikan kepada penyidik untuk dilengkapi lagi. Sebaliknya, jika penuntut umum merasa berkas perkara tersebut telah lengkap, maka berkas perkara tersebut segera dilimpahkan ke Pengadilan Negeri untuk dilakukan pemeriksaan di persidangan.

Proses pemeriksaan di persidangan berjalan sesuai dengan proses acara pemeriksaan biasa. Kemudian berdasarkan fakta dan bukti yang diajukan di persidangan, hakim membuat pertimbangan-pertimbangan lalu menjatuhkan putusan atas perkara pidana memberikan keterangan palsu dibawah sumpah tersebut.

Dari kedua pendapat yang dikemukakan sebelumnya mengenai perlu atau tidaknya tindakan penyidikan oleh kepolisian, pada beberapa kasus yang terjadi para aparat penegak hukum tetap melakukan pemeriksaan apabila adanya laporan di kepolisian mengenai tindak pidana memberikan keterangan palsu di bawah sumpah, dimulai dari penyidikan, penuntutan hingga penjatuhan putusan pidana oleh majelis hakim apabila memang terdakwa terbukti secara sah dan meyakinkan telah melakukan tindak pidana memberikan keterangan palsu dibawah sumpah pada suatu persidangan pengadilan.

\section{KESIMPULAN}

Polisi sebagai penyidik kepolisian berwenang melakukan penyidikan terhadap kasus pidana memberikan keteranan palsu di depan persidangan. Penerapan Pasal 242 tidak hanya terbatas apabila seorang saksi telah ditetapkan oleh hakim telah memberikan keterangan palsu di depan persidangan pengadilan. Tetapi, hal ini juga berlaku apabila saksi tidak dinyatakan oleh hakim telah memberikan keterangan palsu pada saat persidangan berlangsung. Bila setelah memberikan kesaksian di persidangan atau di kemudian hari diketahui bahwa saksi tersebut telah memberikan keterangan palsu, maka ia dapat dilaporkan dan penyidik kepolisian berwenang melakukan penyidikan atas kasus keterangan palsu tersebut. Sebaliknya, Pasal 174 KUHAP tidak mutlak harus digunakan sebagai pertimbangan dalam menyelesaikan perkara keterangan palsu. Penyidik kepolisian tidak perlu melakukan penyidikan apabila hakim menyatakan bahwa saksi tersebut telah memberikan keterangan palsu, dan proses penyelesaian perkara pidana tanpa melalui proses penyidikan, tapi langsung pada penuntutan dengan dakwaan sumpah palsu (Pasal 242 KUHP).

Pasal 242 ayat (1) KUHP perlu ditambahkan unsur "diketahui baik di depan sidang pengadilan maupun di luar sidang pengadilan" untuk mempertegas cakupan tempat di mana pelaku melakukan perbuatan. Selain itu, Pasal 174 ayat (l) KUHAP perlu dipertegas dengan mewajibkan hakim membacakan pasal dalam KUHPidana yang dapat dijadikan dasar penuntutan (Pasal 242 KUHP) dan ancaman pidana maksimum yang ditentukan dalam pasal tersebut. 


\section{DAFTAR PUSTAKA}

Andi Hamzah, Hukum Acara Pidana Indonesia, Sinar Grafika, Jakarta, 2008.

Harahap, M. Yahya, Pembahasan Permasalahan dan Penerapan KUHAP Pemeriksaan Sidang Pengadilan, Banding, Kasasi, dan Peninjauan Kembali, (Jakarta: Edisi Kedua, Sinar Grafika, 2016)

Harahap, M. Yahya, Pembahasan Permasalahan dan Penerapan KUHAP Penyidikan dan Penuntutan, (Jakarta: Edisi Kedua, Sinar Grafika, 2015).

Husin, Kadri \& Budi Rizki Husin, Sistem Peradilan Pidana di Indonesia, (Jakarta: Sinar Grafika, 2016).

Kompas.com Advokat dan Tuduhan Keterangan Palsu http://nasional.kompas.com/read/2015/ 01/28/14341241/Advokat.dan.Tuduhan.Keterangan.Palsu, diakses tanggal 28 Oktober 2017.

Marzuki, Peter Mahmud, Penelitian Hukum, (Jakarta: Edisi Revisi Cetakan ke-12, Prenadamedia Group, 2016).

Mohammad Taufik Makarao, Suhasril, Hukum Acara Pidana dalam Teori dan Praktek, (Jakarta: Ghalia Indonesia, 2004).

Muhadar, Edi Abdullah, Husni Thamrin, Perlindungan Saksi dan Korban dalam Sistem Peradilan Pidana, (Surabaya: Putra Media Nusantara, 2009).

Nurdin, Andriani, "Keterangan Saksi di Sidang Dalam Perkara Pidana yang Disangka Palsu Berdasarkan Pasal 174 KUHAP" (2013) Varia Peradilan Nomor 328.

Rahayu, Yusti Probowati, Dibalik Putusan Hakim (kajian psikologi hukum dalam perkara pidana), (Surabaya: Srikandi, 2005).

Renggong, Ruslan, Hukum Acara Pidana Memahami Perlindungan HAM dalam Proses Penahanan di Indonesia, (Jakarta: Prenadamedia Group, 2014).

Soesilo, R., Kitab Undang-Undang Hukum Pidana (KUHP) Serta Komentar-Komentarnya Lengkap Pasal Demi Pasal, (Bogor: Politeia, 1995).

Soetarna, Hendar, Hukum Pembuktian dalan Acara Pidana, (Bandung: Alumni, 2011). 
226 | Kewenangan Penyidik Kepolisian untuk Melakukan Penyidikan terhadap Kasus Pidana Keterangan Palsu

This page is intentionally left blank 